\title{
Clio
}

Women, Gender, History

$37 \mid 2013$

When Medicine Meets Gender

\section{The gender of cancer}

\section{Ilana Löwy}

\section{(2) OpenEdition \\ Journals}

Electronic version

URL: http://journals.openedition.org/cliowgh/366

DOI: 10.4000/cliowgh.366

ISSN: 2554-3822

\section{Publisher}

Belin

\section{Electronic reference}

Ilana Löwy, «The gender of cancer », Clio [Online], 37 | 2013, Online since 15 April 2014, connection on 30 April 2019. URL : http://journals.openedition.org/cliowgh/366 ; DOI : 10.4000/cliowgh.366

This text was automatically generated on 30 April 2019.

Clio 


\title{
The gender of cancer
}

\author{
Ilana Löwy
}

1 While some cancers are strictly sex-specific, the overall incidence of cancer is nevertheless considered broadly similar in both sexes. ${ }^{1}$ This 'gender-balanced' view is a relatively new development. Until mid-twentieth century, cancer was viewed as a disease that affected mainly women. This view reflected the greater visibility of breast cancer and cancers of the female reproductive organs. Before the advent of modern diagnostic technologies, doctors often failed to diagnose malignant tumors of internal organs. People suffered from digestive troubles, jaundice, "fits," shortness of breath and "the ailments of old age," rather than from stomach, colon, liver, brain or lung cancer. On the other hand, it was difficult to miss the dramatic changes in a cancer-affected breast, or the massive blood loss and abundant vaginal secretions in advanced uterine cancer. In the nineteenth and early twentieth century, mortality statistics in France and England - while far from accurate - recorded nearly three times more cancer deaths among women than among men. The tide turned only in mid-twentieth century, with the increase of accurate diagnoses of malignancies of internal organs and the rapid rise in deaths from lung cancer among men.

2 This article focuses on the period when experts and organizations active in the area of cancer prevention and treatment area spoke mainly about and to women. ${ }^{2}$ Drawing on both primary and secondary research concerning Europe and North America, it explores both the medical discourse and the practices related to the treatment of women's cancers. $^{3}$

\section{Mothers and sinners: female cancers in the nineteenth century}

3 In the nineteenth century, doctors offered a variety of explanations for the high incidence of uterine cancer among women. For some, immorality and sexual excess explained the appearance of malignancies. ${ }^{4}$ The Canadian doctor Guillaume Vallée affirmed in 1826 that lower-class women who lived in cities suffered more often from uterine cancer than those who lived in the countryside, a difference best explained by the 
greater moral laxity of city-dwellers. ${ }^{5}$ Other physicians noted, however, that prostitutes were no more prone to uterine tumors than "honest" women. Still, many physicians enumerated among causes of such tumors masturbation, excessive sexual activity and inordinate sexual desire, syphilis and other venereal diseases, abortion, as well as disorders of women's "critical age" (menopause).

In 1842, a surgeon from Padua, Domenico Rigoni-Stern, demonstrated that nuns rarely suffered from cancer of the womb, while they had higher than average frequency of breast tumors. ${ }^{6}$ The observation that the same group of women was unusually susceptible to one kind of malignant tumor and unusually resistant to another kind, challenged the widespread belief that the principal cause of cancer was a moral propensity or a hereditary predisposition to develop malignancies ("cancer diathesis"). Rigoni-Stern's observations also suggested that cancer of the womb might be linked with sexual activity. The British physician J.W.C. Lever similarly stated in 1839 that unmarried women rarely suffered from cancer of the uterus, suggesting ${ }^{7}$ that the development of this pathology might be favored by childbirth. By the late nineteenth and early twentieth century, this opinion had become widespread, and many gynecologists became persuaded that uterine cancer was linked not to sexual excess, but to the damage produced by multiple pregnancies and traumatic childbirth.

For much of the nineteenth century, doctors talked about a single type of cancer, that of "the matrix", but by the later years of the century, experts were making a distinction between cancer of corpus uteri (later known as endometrial cancer), and - the then much more frequent - cancer of the uterine cervix (cervical cancer). They believed that only the latter disease was linked with low socio-economic status and with post-partum damage. Cervical cancer was more frequently found in poorer women, because they had more children and had less means of access to proper medical care when they gave birth, so were likely to suffer from more severe cervical tears. ${ }^{8}$ Poverty was also linked to faulty hygiene, higher frequency of sexually transmitted diseases, miscarriage and abortion, all of which facilitated the development of chronic inflammation of the cervix, seen as a precursor lesion of cervical malignancy. Sexuality was not entirely absent from the argument on links between poverty and uterine tumors, since sexually transmitted diseases and abortions were seen as the consequence of the supposedly more lax sexual mores of lower-class women. However, in the first half of the twentieth century, numerous gynecologists believed that a higher occurrence of cervical cancer among poor women was chiefly the result of frequent pregnancies, inadequate medical care, and harsh living conditions. This cancer had become the scourge of the poor mother.

\section{Detecting and treating female malignancies}

6 In the early nineteenth century, many physicians assumed that they could prevent at least some of the suffering produced by uterine cancer through the treatment of cervical lesions ("squirrhus") before they became an irreversible "cancer". ${ }^{9}$ In 1836, the French gynecologist Pierre Téallier compared this preventive treatment of suspicious gynecological lesions with the prevention of social unrest through the repression of its first manifestations, both being more effective the earlier they were tackled. ${ }^{10}$ Téallier, like other cancer experts, emphasized the importance of medical consultations as soon as women observed suspicious symptoms, such as irregular bleeding. This was, however, a difficult task. Women were reluctant to consult for minor gynecological troubles, and 
most women did not have the financial means to do so. As a result, they often saw a doctor only when their tumor induced more serious symptoms. At that stage, specialists wrote, the illness was incurable and the physician could only observe its inexorable progress. ${ }^{11}$

With the development of surgical ablation of the uterus (hysterectomy) in the late nineteenth century, doctors were finally able to propose a therapy for uterine malignancies. Hysterectomy was at first a very hazardous form of surgery with a high mortality rate, but gynecologists believed that it should be attempted when possible, given the alternative of a slow and painful death. In the early twentieth century, survival rates of hysterectomy had improved, but this operation was ineffective if the cancer had already spread to other parts of the body. ${ }^{12}$ Physicians continued therefore, this time with more solid arguments, to urge women to consult a doctor as soon as they observed any suspicious gynecological symptoms. Their goal was to increase the proportion of tumors detected in an "operable" stage, that is, those limited to the uterus only. ${ }^{13}$

Anti-cancer organizations in Europe and North America energetically promoted the slogan, "if detected early, cancer can be cured". If one reads this phrase carefully, it merely states that while some localized malignant tumors are curable, all the disseminated ones are deadly. The usual interpretation of this slogan was, however, different. It strongly hinted that a patient who knows what early signs of cancer are, and who promptly consults a competent doctor on observing such signs, has a good chance of being cured. It also indirectly implied that patients who died from cancer might have been at least partly responsible for their fate. ${ }^{14}$ Educational campaigns organized by cancer experts and anti-cancer organizations often focused on female cancers (of breast and uterus), which were considered "treatable". Such campaigns promoted an upbeat message and downplayed the harsh realities and uncertain results of cancer treatment. ${ }^{15}$

\section{Early detection of cancer of the uterus}

Thanks to the "early detection" campaigns for cervical cancer, many women became persuaded that they should see a physician rapidly if they observed symptoms such as irregular bleeding. ${ }^{16}$ In the inter-war period, gynecologists discovered, however, that not infrequently a woman who consulted them immediately after noticing suspicious gynecological symptoms had a disseminated, that is, incurable malignancy. The "early" medical visit was sometimes too late. The next step was to persuade "asymptomatic" (that is, healthy) women to undergo regular gynecological examinations, in order to detect "silent" cervical lesions. ${ }^{17}$

In 1938, the Philadelphia gynecologist Catherine Macfarlane began a pilot program for an early detection of cervical cancer. M Macfarlane's original project was to provide free gynecological examinations in poor areas of the city. Poor women, especially black women, had the highest frequency of uterine tumors. Since they could not afford visits to a gynecologist, they were often diagnosed with advanced, incurable malignancies. The local medical community, and the administrators of Women's Medical College to which she was affiliated, strongly opposed Macfarlane's project, because physicians were afraid that a free distribution of medical services would reduce their private practice and introduce a dangerous percentage of "socialized medicine". The Women's Medical College finally approved the project, but on condition that Macfarlane would examine only 
women referred by their physicians - that is, those who could afford private health care. Macfarlane's program provided important insights into the natural history of cervical tumors but was of no assistance to women who had the greatest need for early detection of this malignancy. ${ }^{18}$

In the 1950s, physicians developed a cheaper and simpler alternative to regular gynecological visits: the cervical smear (Papanicolau or PAP test). The test was laborintensive and difficult to standardize, but was nevertheless successfully transformed into a "workable" tool in screening for the presence of anomalies of the cervix. ${ }^{19}$ Cancer specialists and organizations in North America and Europe strongly promoted cervical smears. The UK campaigns had a direct public health dimension. Educational films produced in the UK in the early 1960s specifically targeted working class and migrant women. These films sought to eliminate women's fear of "the test" and of the treatment involved if suspicious cervical lesions were found. They encouraged women to take responsibility for their own health, but above all stressed their duty, as mothers, to be healthy for the sake of their children and partners. The films explained that treatment of precancerous cervical lesions was simple and without danger for woman's fertility or sexual life. The latter affirmation was designed to persuade husbands, who sometimes opposed testing for cervical tumors. Another argument directed at husbands was that a spouse's serious disease would disrupt their lifestyle: "no more nights out at the pub, no more football on Saturdays, just staying home with all those noisy kids." ${ }^{20}$

In the US, cervical cancer was not presented as a public health issue or a pathology linked with a lower socioeconomic status, but as an individual problem: every woman, these films explained, was at risk from this disease. Accordingly, educational films in the US on the importance of screening for cervical malignancies mainly showed middle-class women in a middle-class setting. These films explained that regular PAP smears offered women security, personal happiness and freedom from the threat of cancer. ${ }^{21} \mathrm{At}$ the same time, US educational materials also emphasized a woman's duty to herself and her family to undergo regular tests, and hinted that women who developed cervical cancer were, at some level at least, responsible for their fate.

\section{Early detection of breast cancer}

Breast cancer was another malignancy presented as curable if detected early. Specialists urged women to be vigilant about changes in their breasts, and if they discovered a lump or other suspicious change, to consult a doctor immediately. "Delaying" a medical consultation, even by a few weeks, was presented as highly irresponsible behavior, which deprived the "delaying" woman of any chance of a cure. After World War II, the "do not delay" message was reinforced by the introduction of breast self-examination technique (BSE); women were urged to do this monthly. The American Cancer Society published posters and leaflets in the 1950s and 60s explaining the dangers associated with the neglect of BSE, illustrating its argument with testimonies by women who claimed that the examination had saved their lives or, occasionally, that they were dying from cancer because they had failed to perform BSE regularly. ${ }^{22}$ These educational materials transmitted an implicit message that advanced breast cancer was a self-inflicted disease. BSE was advocated in Europe too, although it was less widely adopted there than in the $\mathrm{US}^{23}$ 

trials conducted in the 1990s had shown that it was not very efficient, perhaps because this technique allowed them to believe that they could protect themselves from a dread disease. ${ }^{24}$ Mammography screening was developed in the 1960 s and 70 s, and was massively diffused from the 1980s on, in spite of persistent controversies about the efficacy of this approach. Its rapid spread may be partly explained by women's intense attachment to this method, which gave them the impression, once more, that they could themselves control the risk of getting breast cancer. ${ }^{25}$ Debates on the benefits of mammography remained, in the main, confined to specialists, and had limited visibility in the public space. ${ }^{26}$ The majority of anti-cancer organizations enthusiastically supported mammography screening, and women have tended to entertain very exaggerated ideas about the capacity of this technique to reduce breast cancer mortality. ${ }^{27}$ In a survey carried out in 2009, $2 \%$ of French women gave an accurate estimate of the effectiveness of mammography, $15 \%$ exaggerated its efficacy 10 times; 22\%, 50 times; and 45\%, 100 times or more (16\% answered that they did not know). ${ }^{28}$

Before the 1980s, women were invited to follow their doctor's advice. Posters and propaganda films from that period frequently show a subdued and conservatively dressed woman attentively listening to a male medical practitioner. By contrast, educational materials from the last 30 years emphasize women's self-empowerment, and show energetic, youthful and smiling women who proudly proclaim they take good care of themselves through a regular screening of their breasts. ${ }^{29}$ In spite of great differences of language and style, the message promoted in the $21^{\text {st }}$ century is not very different from the one propagated in the pre-women's liberation period. Women are asked to submit themselves to external control, and, at the same time, to appeal to clinical specialists. In the apt expression of the sociologist Ann Robertson, they are urged to "swallow the panopticon." ${ }^{30}$

\section{Women doctors and female malignancies}

In the nineteenth and early twentieth century, the only cure for cancer was surgery, often of a radical kind. At the time, there were not many female doctors, and even fewer female surgeons. Women who chose a surgical career often specialized in "female diseases," including cancer. One of the early pioneers of surgical treatment of cancer of the uterus in the US was Mary Dixon-Jones. Dixon-Jones had a far from orthodox career. First trained in general medicine, and practising homeopathy and hydrotherapy, she retrained as a surgeon in her late forties. She then founded the Women's Hospital of Brooklyn, specializing in surgical treatment of gynecological diseases. Mary Dixon-Jones was the first US surgeon to perform an ablation of the uterus in 1888, and believed that this surgery should be proposed not only to women with confirmed cancer, but also to those at risk of this disease..$^{31}$ In the late nineteenth century, doctors concurred that many of women's health problems were linked to their reproductive functions. Nevertheless attitudes towards surgical ablation of female reproductive organs, uterus and ovaries, as a cure for "female diseases," varied greatly. Some gynecologists strongly supported this therapeutic approach, while others strongly criticized it..$^{32}$ The controversial reputation of gynecological surgery coupled with high mortality rates, and in the case of Dixon-Jones a suspicion attached to women surgeons, produced an explosive mix. 
In 1889, Dixon-Jones was accused of second degree manslaughter after the death of her patient Ida Hunt. The historian Regina Marantz Sanchez, who has studied Dixon-Jones's tumultuous career, presents evidence that Ida Hunt was a chronically ill young woman, probably as a consequence of venereal disease acquired from her husband. Her surgery may have been a last ditch effort to regain her lost health. Some women, MarantzSanchez argues, sought Dixon-Jones's clinic precisely because she advocated radical surgical measures. ${ }^{33}$ This was, however, a risky practice. Dixon-Jones was acquitted of manslaughter, but a local newspaper, The Brooklyn Daily Eagle published a series of articles accusing her of gratuitous cruelty to her patients, performing ill-advised operations, and being guilty of negligence and incompetence. Dixon-Jones unsuccessfully sued The Brooklyn Daily Eagle for libel in 1892. Unable to clear her name in a highly publicized trial, Dixon-Jones was obliged to abandon the directorship of her hospital and her surgical practice. $^{34}$

Surgical ablations of the uterus performed by the British surgeons Louisa Garrett Anderson and Kate Platt were less controversial. Between 1901 and 1914 Anderson and Platt co-directed the surgical ward of the London's New Hospital for Women, which specialized in gynecological operations. They strongly advocated radical surgery for uterine tumors, a practice they developed in the late 1890s, and expanded in the first decade of the twentieth century. In the 1880s, a quarter of all women who underwent an ablation of the uterus died from its immediate effects or from post-operative infections. By 1908, Anderson and Platt could boast that this surgery had become much less dangerous; the mortality rate at their hospital was only $6.6 \%$. They admitted that the chance of a permanent cure of cancer through this operation was not very high, but, they argued, even a low chance of cure was better than a certainty of a lingering, painful death..$^{35}$

19 Female surgeons such as Mary Dixon-Jones or Louisa Garrett Anderson embraced the male surgeons' ethics of daring behavior and willingness to take risks. This choice may have been motivated by an aspiration to demonstrate that, as professionals, women were no different from men. Other women physicians chose a different approach. They saw themselves as spokespersons for their sex, and promoted treatments which they believed were less harmful and more acceptable for women. Thus in Britain, women played an important role in the development of radiation therapy for gynecological malignancies, above all cancer of the cervix. In 1929, the British Medical Women's Federation provided funding for the Marie Curie Hospital, dedicated to radiation therapy of gynecological cancers and staffed exclusively by women doctors. Leaflets presenting the new hospital explained that women nervous about consulting a male doctor would be able to talk to another woman, who would able to understand the precise nature of their complaint. The literature also reassured poorer people, who were often apprehensive about operations in charity hospitals, fearing that doctors would use their bodies to test experimental surgical techniques. Radiation therapy did not generate such fears. ${ }^{36}$

Women physicians were also attracted to radiation therapy for cancer because this domain opened new professional opportunities for them. In interwar France, a woman doctor had no chance whatever of achieving prominence in the French medical hierarchy, of becoming an agrégée de médecine, or head of department in a university hospital, or of being appointed to a university chair. Institutions such as the Curie Foundation in Paris, and the Villejuif Cancer Institute, at the margins of the official academic medicine system, were more able to promote women's careers. Several women 
physicians became pioneers of "curietherapy" - the French term for radiation therapy. One of them, Simone Laborde, head of the radiation therapy service at the Villejuif Cancer Institute, developed in the 1930s an innovative approach to radiotherapy. Cancer, Laborde argued, is not an alien enemy but a diseased part of the body. The destruction of healthy tissues through excessive radiation not only produced more severe side effects, but reduced the body's ability to deal with malignant cells. Laborde strongly opposed therapeutic strategies grounded in the belief that in the "war against cancer" more is always better. ${ }^{37}$ Her objections to "heroic therapies" may have been grounded in awareness of the concrete experience of her patients. Some women feared secondary effects of radiation more than the cancer itself. One Canadian woman who refused to undergo radiotherapy for cancer of the uterus in the 1930s explained that,

three of my friends had similar treatment and they told me they were dying a death of a fiery internal furnace. Knowing of their untimely deaths and awful agony, I was determined to die comfortably, if needs be by the inroads of cancerous growths. ${ }^{38}$

\section{Preventive surgery and women: from the nineteenth to the twenty-first century} experts viewed cancer as a particularly dangerous enemy, and many saw the preventive elimination of "precancerous" tissues and organs as an especially efficient way to fight this enemy ${ }^{39}$ This approach was, however, limited almost exclusively to women's cancers. The accessibility of these cancers explains in part why they became targets of preventive surgery. Another and perhaps even more important reason was the existence of a long tradition of surgical excision of women's reproductive organs, whether diseased or healthy. ${ }^{40}$

Feminists have often criticized doctors' lack of sensitivity to women's needs, and their wish to control female reproductive functions. Already in the nineteenth century, activists protested against the surgical ablation of ovaries ("the de-sexing of women") and unnecessary hysterectomies. They presented these operations as typical expressions of the brutal treatment of women by the medical profession..$^{41}$ Recent scholarship has nuanced this interpretation, however, suggesting that radical surgery was directed more against tumors than against women. Writing about the medical culture of breast cancer treatment in the nineteenth century, Erin O'Connor has argued that the nineteenth century discourse about breast cancer reflected the harsh reality of suffering induced by advanced breast malignancies. Doctors who watched women die painful deaths desperately tried to do something to prevent such deaths..$^{42}$ The feminist sociologist Barbara Rothman has similarly concluded that surgeons who opposed conservative surgery for breast cancer were not driven by misogyny but by a concern to do the best for their patients while limiting their own risk of making medical mistakes. ${ }^{43}$

Attitudes towards radical surgical treatment of already existing and invasive malignancies were indeed not very different for both sexes. Men also had a full share of "heroic" and mutilating surgeries, notably for the treatment of head and neck tumors. The latter tumors, linked to smoking and to alcohol consumption, were more frequently found in men. On the other hand, surgery for the elimination of a cancer risk - that is preventive ablation of breasts, ovaries and the uterus - was almost exclusively practiced on women. One exception was a rare hereditary form of colon cancer, familial 
adenomatous polyposis, treated by preventive removal of the colon. However, in the latter case, prophylactic surgery was proposed only to people (of both sexes) who were almost certain to develop colon cancer. Breast cancer was a very different case. Doctors recommended preventive surgery to women even for lesions whose probability of becoming cancerous were unknown: e.g., women with precancerous transformations of breast tissue (ductal carcinoma in situ, or DCIS), and carriers of mutations of the BCRA gene which increased their chances of developing breast and ovarian tumors. ${ }^{44}$

American epidemiologists claimed that women presenting with a small tumor in the breast, or genetic predisposition to this cancer were increasingly opting for preventive removal of both breasts. ${ }^{45}$ Such a radical decision was linked to

the never-ending awareness campaigns that have left many women in perpetual

fear of the disease [...] Because breast cancer is a disease that is so emotionally

charged and gets so much attention, I think at times women feel almost obligated to

be as proactive as possible - that's the culture of breast cancer. ${ }^{46}$

Preventive treatment of cancers of the female reproductive organs - which may be contrasted with the more conservative treatment of risk of cancer in the male reproductive organs - may have been encouraged by the greater visibility of these pathologies. ${ }^{47}$ Such visibility probably reflects the long tradition of debates and public campaigns focused on women's cancers. Breast cancer is omnipresent in the media and in the public space. It has also became a quasi-ritualized literary topic, with a flood of "pathographies" (personal narratives of diseases), essays, novels, photographs and other art works. This is not the case for prostate cancer. In spite of its high incidence, prostate cancer is rarely discussed in the media and popular books, and is seldom noticeable in the public space. ${ }^{48}$ In spite of its "official" image as a disease that strikes indiscriminately at both sexes, in the twenty-first century too cancer remains a gendered pathology.

\section{BIBLIOGRAPHY}

ARONOWITZ, Robert. 2001. Do not delay: breast cancer and time 1900-1970. The Milbank Quarterly 79 (3): 355-386.

ARONOWITZ, Robert. 2007. Unnatural History: breast cancer and American society. New York.

Cambridge University Press.

BANKS, James, MARMOT, Michel, OLDFIELD, Zoe, and James P. SMITH. 2006. Disease and disadvantage in the United States and England. Journal of the American Medical Association 295(17): 2037-2045.

BLOoDGooD, Joseph Colt [circa 1916] What Every One Should Know About Cancer. AMA leaflet: 4-6. BURSTEIn, Harold J., POLYAK, Kornelia, WONG, Julia, LESTER, Susan, and Carolyn M. KAELIN. 2004. Ductal carcinoma in situ of the breast. New England Journal of Medicine 350(14): 1430-1441.

CANTOR, David. 2007. Uncertain enthusiasm: the American Cancer Society, public education and the problem of the movie, 1921-1960. Bulletin of the History of Medicine 81(1): 39-69. 
CASPER, Monica J., and Adele E. CLARKE. 1998. Making Pap smear into the 'right tool' for the job: cervical cancer screening in the USA, circa 1940-1995. Social Studies of Science 28(2): 255-290. CLOW, Barbara. 2001. Who's afraid of Susan Sontag? Or the myths and metaphors of cancer reconsidered. Social History of Medicine 14(2): 293-312.

DIXON-JONES, Mary A. 1893. Colpo-hysterectomy for malignant disease. American Journal of Obstetrics and Diseases of Women and Children 27(4-5): 107-118.

EISINGER, François, GELLER, Gail, BURKE, William, and Neil. A. HOLTZMAN. 1999. Cultural basis for differences between and French clinical recommendations for women at increased risk of breast and ovarian cancer. The Lancet 353: 919-920.

GARDNER, Kirsten E. 2006. Early Detection: women, cancer, and awareness campaigns in the twentiethcentury United States. Chapel Hill. University of North Carolina Press.

GARRETT ANDERSON, Louisa, and Kate PLATT. 1908. Malignant disease of the uterus: a digest of 265 cases treated in the New Hospital for Women. Obstetrics and Gynaecology of the British Empire 14(6): 381-392.

GIGERENZER, Gert, MATA, Jutta, and Ronald FRANK. 2009. Public knowledge of benefits of screening for breast and prostate cancer in Europe. Journal of the National Cancer Institute 101(17): 1216-1220. GREEN, Beverly B., and Stephen H. TAPLIN. 2003. Breast cancer screening controversies. Journal of the American Board of Family Medicine 16(3): 233-241.

GROOPMAN, Jerome. 2000. The Prostate Paradox: prostate cancer. The New Yorker, 29 May: 52-64.

HACKSHAW, Allan K., and Elizabeth A. PAUL. 2003. Breast self-examination and death from breast cancer: a meta-analysis. British Journal of Cancer 88(7): 1047-1053.

HUGENIN, René. 1946. L'apport de la France dans l'étude du cancer. In Ce que la France a apporté à la médicine, ed. A. Théophile ALAJOUANINE et al., 141-172. Paris. Flammarion.

JANSEN, Patricia. 2011. Menopause and the construction of cancer risk. Canadian Bulletin of Medical History 28(1): 43-70.

JORGERSEN, Karsten Juhl, and Peter GOTZSCHE. 2004. Presentation of websites on possible benefits and harms from screening for breast cancer: cross sectional study. British Medical Journal 328: 148-154.

KING, Samantha. 2006. Pink Ribbons Inc.: breast cancer and the politics of philanthropy. Minneapolis. Minnesota University Press.

KLOTZ, Laurence. 2006. Active surveillance with selective delayed intervention for favorable risk prostate cancer. Urological Oncology 24(1): 46-50.

LAUDON, Irving. 1988. Maternal mortality (1880-1950): some regional and international comparisons. Social History of Medicine 1(2): 183-228.

LEGOUX, Léon. 1826. Considérations sur les maladies cancéreuses en général. Paris. Didot le Jeune.

LERNER, Barron. 2001. The Breast Cancer Wars: hope, fear and the pursuit of a cure in twentieth-century America. New York. Oxford University Press.

LEVER, John Charles Weaver. 1839. Statistical notices on one hundred and twenty cases of carcinoma uteri. Medico-Chirurgical Transactions 22: 267-273.

LÖWY, Ilana. 2009. Preventive Strikes: women, pre-cancer and preventive surgery. Baltimore. Johns Hopkins University Press. 
LöWY, Ilana. 2011. Woman's Disease. Oxford. Oxford University Press.

MACFARLANE, Catherine, STURGIS, Margaret C., and Faith FETTERMAN. 1953. Periodic examination of the female pelvic organs and breasts: a report of fifteen years research on the control of cancer. CA, Cancer Journal for Clinicians 3: 205-207.

MEIGS, Charles D. 1859 [4 th $^{\text {edn] }}$. Woman: Her Diseases and Remedies. Philadelphia. Blanchard \& Lea. MILLIGAN, Anstruth. 1907. The crusade against cancer of the uterus. Journal of Obstetrics and Gynaecology 11: 45-63.

MORANTZ-SANCHEZ, Regina. 1999. Conduct Unbecoming a Woman: medicine on trial in nineteenth-century Brooklyn. New York. Oxford University Press.

MORANTZ-SANCHEZ, Regina. 2000. Negotiating power at the bedside: historical perspectives on nineteenth-century patients and their gynaecologists. Feminist Studies 26(2): 287-309.

MOscuccI, Ornella. 1990. The Science of Woman: gynaecology and gender in England, 1800-1929.

Cambridge. Cambridge University Press.

MOSCUCCI, Ornella. 2005. Gender and cancer in Britain, 1860-1910: the emergence of cancer as a public health concern. American Journal of Public Health 95(8): 1312-1321.

MOscuccI, Ornella. 2007. The ineffable masonry of sex: feminist surgeons and the establishment of radiotherapy in early twentieth-century Britain. Bulletin of the History of Medicine 81: 139-163.

MUKHERJEE, Siddhartha. 2010. The Emperor of all Maladies: a biography of cancer. New York. Simon and Schuster.

NEKHLYUdOV, Larissa, ROSS-DEGNANT, Denis, and Susanne W. FLETCHER. 2003. Beliefs and expectations of women under 50 years old regarding screening mammography. Journal of General Internal Medicine 18: 182-189.

NOLTE, Karen. 2008. 'Carcinoma uteri' and 'debouchery-morality, cancer and gender in the nineteenth century'. Social History of Medicine 21(1): 31-46.

O'CONNOR, Erin. 2000. Raw Material: producing pathology in Victorian culture. Durham, N.C. Duke University Press.

PATTERSON, James. 1987. The Dread Disease: cancer and modern American culture. Cambridge, Mass. Harvard University Press.

PARKER-POPE, Tara. 2013. Facing cancer, a stark choice. New York Times, 21.1.2013.

PICHEVIN, Antoine. 1912. La lutte contre le cancer d'utérus. Journal de Médicine de Paris: 151-153.

REAGAN, Leslie. 1997. Engendering the dread disease: women, men and cancer. American Journal of Public Health 87(11): 1179-1187.

ROBERTSON, Anne. 2001. Biotechnology: political rationality and discourses on health risk. Health 5/3: 293-309.

ROSSIGNOL, Jean Auguste. 1806. Essai sur le cancer de l'utérus. Montpellier. Imprimerie Coucourdan. ROTHMAN, Barbara Katz. 1998. The Book of Life: a personal and ethical guide to race, normality and the implications of the Human Genome Project. Boston. Beacon Press.

SCOTTO, Joseph, and John BAILARD. 1969. Rigoni Stern and medical statistics: a nineteenth-century approach to cancer research. Journal of the History of Medicine and Allied Sciences 24(1): 65-75. 
TÉALLIER, Pierre Jérôme Sébastien. 1836. Du Cancer de la matrice, de ses causes, son diagnostic et son traitement. Paris. Ballière.

TOON, Elisabeth. 2007. Cancer as the general population knows it: knowledge, fear and lay education in twentieth-century Britain. Bulletin of the History of Medicine 81(1): 116-138.

VALLÉE, Guillaume. 1826. Dissertation sur le cancer de l'utérus. Paris. Imprimerie Didot Jeune.

WALKoWITZ, Judith. 1980. Prostitution in Victorian Society: Women, Class and the State. Cambridge.

Cambridge University Press.

WARDLE Jane, STEPTOE Andrew, SMITH Heather et al. 1995. Breast self-examination: attitudes and practices among young women in Europe. European Journal of Cancer Prevention 4(1): 61-68.

WELCH, Gilbert. 2004. Should I be Tested for Cancer? Maybe not and here's why, Berkeley. University of California Press.

\section{NOTES}

1. Banks et al. 2006. Their data deal only with overall frequency of cancers, and not with the distribution of specific cancers.

2. Reagan 1997; Moscucci 2005; Jansen 2011.

3. Aronowitz 2001; Gardner 2006; Löwy 2009 and 2011.

4. Nolte 2008. Breast cancer was less strongly linked with specific lifestyle elements than cancer of the womb.

5. Vallée 1826: 10.

6. Scotto \& Bailard 1969.

7. Lever 1839.

8. Laudon 1988: 183-228.

9. Meigs 1859: 333.

10. Téallier 1836: 108.

11. Rossignol 1806: 23; Legoux 1826: 35.

12. Moscucci 2005.

13. Bloodgood [ca 1916].

14. Patterson 1987; Lerner 2001.

15. Gardner 2006: 53-92.

16. Milligan 1907; Pichevin 1912.

17. Annual rapport of the Curie Foundation for 1932. Minutes of meeting of the foundation's administration council of 4 May 1934. Curie Institute Archive, Paris.

18. Catherine Macfarlane papers. Medical College of Philadelphia archive, account 47, Box 2, Folder 23, typed ms "The inside history of periodic pelvic examination research"; Macfarlane, Sturgis \& Fetterman 1953.

19. Casper \& Clark 1998.

20. Wellcome Library, Archives and Manuscripts Dept, series SA/MWF, Documents of the Medical Women Federation, File F.13/10. Documents from the Meeting of the "Film Working Party of the Women's National Cancer Control Campaign," 13/12/67.

21. Cantor 2007.

22. Aronowitz 2001; Gardner 2006.

23. Wardle et al. 1995; Eisinger et al. 1999.

24. Green \& Taplin 2003; Hackshaw \& Paul 2003. 
25. The diffusion of mammography coincided with a reduction in breast cancer mortality in many industrialized countries. However, the spread of this technique also coincided with the development of important therapeutic innovations. It is therefore difficult to evaluate the mammography's contribution (if any) to this decline in breast cancer mortality. Welch 2004.

26. Jorgersen \& Gotzsche 2004.

27. Nekhlyudov, Ross-Degnant \& Fletcher 2003.

28. Gigerenzer, Mata \& Frank 2009. Women also had exaggerated perceptions of the contribution of mammography to the reduction of the number of mastectomies.

29. Gardener 2006; Toon 2008.

30. Robertson 2001: 293-309.

31. Dixon-Jones 1893.

32. Moscucci 1990.

33. Morantz-Sanchez 2000: 301.

34. Morantz-Sanchez 1999.

35. Garrett Anderson \& Platt 1908.

36. Moscucci 2007: 158. Radiotherapy for cancer was introduced in the 1910s; by contrast chemotherapy for breast and uterine tumors became routine treatment of these malignancies only in the 1980s.

37. Quoted by Hugenin 1946: 166.

38. Clow 2001: 301.

39. Siddhartha Mukherjee's bestselling book, The Emperor of all Maladies: a biography of cancer illustrates the continued popularity of the concept of a "war against cancer". Mukherjee 2010.

40. Moscucci 1990.

41. Walkowitz 1980; Moscucci 1990.

42. O'Connor 2000: 78-99. O'Connor is aware of the misogyny of nineteenth-century surgeons, but argues that it did not play an important role in their choice of cancer treatments.

43. Rothman 1998: 154-158.

44. Burstein et al. 2004; Aronowitz 2007: 257-282.

45. Lerner 2001.

46. Parker-Pope 2013.

47. E.g., Groopman 2000; Klotz 2006.

48. On the political underpinning of breast cancer charities activities see e.g. King 2006.

\section{ABSTRACTS}

Today cancer is seen as a disease that affects both sexes roughly equally. This is, however, a relatively recent development. Until the mid-twentieth century, cancer was viewed as a pathology mainly affecting women, because female malignancies produced typical symptoms, and were easier to detect. In the twentieth century, women's cancers - of breast and uterus became the principal targets of public campaigns to promote the early detection of malignant tumours. From the 1950s on, the development of more efficient diagnostic methods and the increase in the prevalence of lung cancer, a disease found more often in men, put an end to the image of cancer as a female pathology. On the other hand, cancers of female reproductive organs continue to be more visible in public discourse and the media than those of male reproductive 
organs, and preventive - and mutilating - forms of surgery are more often proposed for women at risk from these pathologies.

\section{INDEX}

Keywords: malignant tumours, breast cancer, cervical cancer, mastectomy, hysterectomy, PAP smear, early detection, preventive surgery, cancer charities, propaganda films

\section{AUTHOR}

\section{ILANA LÖWY}

Ilana Löwy is a biologist and historian of science and directs research at the Institut national de la santé et de la recherche médicale (INSERM/ CERMES) in Paris. Her own research is on the interaction of bio-medecine and gender studies in a number of fields. Her many publications include Preventive Strikes: Women, Precancer and Prophylactic Surgery, (2009); A Woman's Disease: A History of Cervical Cancer, (2011); with Catherine Marry, Pour en finir avec la domination masculine : de A à $Z$ (2007). She has co-edited with Delphine Gardey, L'Invention du naturel. Les Sciences et la Fabrication du masculin et du féminin (2000), and with Hélène Rouch, La Distinction entre sexe et genre. Une Histoire entre biologie et culture, special number of Cahiers du genre (2003).

lowy@vjf.cnrs.fr 